\title{
An Empirical Analysis of the Antecedents and Performance Consequences of Using the Moodle Platform
}

\author{
Chun-Che Huang, Yu-Min Wang, Tsin-Wei Wu, and Pei-An Wang
}

\begin{abstract}
With the rapid development of the Internet, constructing the e-learning system has been an integral part of many educational institutions. This study uses the Moodle system to make up for the shortcomings of learning in a large class, and find out the difference of learning performance and acceptance between traditional learning and digital learning. The study is experimented with the students in the Calculus course. There are two part of research design in the study. The first part corresponds to learning performance, which uses the quasi-experimental method to compare the difference of the experimental group, and the control group. The second part refers to technology acceptance, where the unified theory of acceptance use of technology (UTAUT) is used. With two dimensions: Outcome Expectation and Attainment Value, a new hybrid technology acceptance model is proposed to investigate the students' intentions to use Moodle systems. Data Analysis of this study shows a great promising in providing new academic research evidence in e-learning teaching.
\end{abstract}

Index Terms-E-Learning, moodle system, UTAUT model, learning performance.

\section{INTRODUCTION}

With the rapid popularization and development of the Internet, construction of digital learning system is an integral part of many educational institutions. Many researchers pointed out that learning through digital learning platform is helpful for students learning [1], [2].

In a large class, students are often up to more than two hundred. It often can't take into account the individual differences of each student. We can find the traditional teaching methods lacks of effective learning interactive learning effectiveness. However, by collaborative learning on the Internet over the network learning platform, students can learn together to enhance the interaction between learners learning. This study will design a study to understand the digital learning methods applied to the traditional large teaching class to enhance learners' learning effectiveness and understand the impact of learner, an important factor for the acceptance of digital learning technology.

In this study, to promote and enhance the effectiveness of learning, students use Moodle learning system in the internship courses. The study also desire to understand the student's acceptance of Moodle system, as well as to explore whether improved learning outcomes for students to change the mode of learning. The main research purposes of this study are as follows: (1) What is the important factors that affect students' intention when they use Moodle for online

Manuscript received October 25, 2012; revised January 13, 2013.

The authors are with Nation Chi Nan University, Taiwan 545, R.O.C. (e-mail: ymwang@ncnu.edu.tw). internship learning? (2) The teaching group quasi-experimental research method is divided into the traditional control group, a group of online teaching group and mixed teaching group. With the experiment, the effectiveness of learning of different groups is different?

Up to date, researchers are confronted with a choice among numerous models to "choose" constructs, or choose a "favored model" and discard alternative models. Therefore, Venkatesh [3] developed an integrated management theory, Unified Theory of Acceptance and Use of Technology (UTAUT). This theory aims at understanding user behavior intention construct; and furthermore enhances the implication of user behavior. Numerous studies has applied UTAUT in different domains and proven more than $70 \%$ of studies with effective experiment results. UTAUT has been applied in e-learning, for example Van Raaij and Schepers [4], Keller, Hrastinski and Carlsson [5], and Chiu and Wang [6]. However these studies do not consider the collaborative learning on the Internet over the network learning platform, e.g., using Moodle.

Moodle is an Open Source Course Management System (CMS) which is provided freely. Moodle is programmed in PHP by Martin Dougiamas, Australia. He developed it as a tool for his dissertation which was on a Socio-constructivist approach to learning (Official Website : http://moodle.org/). The word Moodle was originally an acronym for Modular Object-Oriented Dynamic Learning Environment. It can be installed on any personal computer, educational institution webserver or website, and one also can modify it in what he needs under the GNU General Public License. Mainly effective is help educators or institutions to serve the majority of the online learning community. It offers a variety of modular, powerful and flexibility in the use of the teaching and learning environment, stressed WYSIWYG facilitate teachers learning activities edit interface [7], [8].

\section{RESEARCH METHOD}

In this study, understanding of the students using the Moodle e-learning system calculus internship course learning outcomes and technology acceptance factors in the design of the study is divided into two parts: use experimental research for learning outcomes, experimental packet comparing the experimental group and control group. The digital learning technology acceptance is based on the UTAUT as the theoretical basis.

\section{A. Research Design and Hypothesis}

In order to understand learning differences of the different learning groups used in calculus internship course, this part take a quasi-experimental design to experiment. The 
experimental subjects are undergraduate 100 students. Total experimental groups were divided into three groups, divided into the control group, experimental group 1 and experimental group 2. The control group of students attend internship training course in classroom same as before, in way of traditional face-to-face. The experimental group1 students take the traditional class training, as well participate in online internship course. The experimental group 2 students only participate in online internship. Experiments conducted cycle a total of nine weeks. Pretest is based on the grades in the first semester calculus. Posttest is based on the midterm results. The different modes of teaching should have different learning effects on students' learning effectiveness. Therefore, this study assumes that the three groups of students in the effectiveness of learning will vary in different teaching model.

\section{B. Research Design of Technology Acceptance}

This study understands the technology acceptance in accordance with the Unified Theory of Acceptance and Use of Technology (UTAUT) [3], as the theoretical basis to modify. The main purpose is in the application of the Unified Theory of Acceptance and Use of Technology (UTAUT) affecting students using the Moodle e-learning system factors In addition, according to the relevant literature that the results expected and achievements value will affect the intention to use, so we join these two dimensions to UTAUT model to analyze whether also factors that affect students' use of digital learning system (Fig. 1)

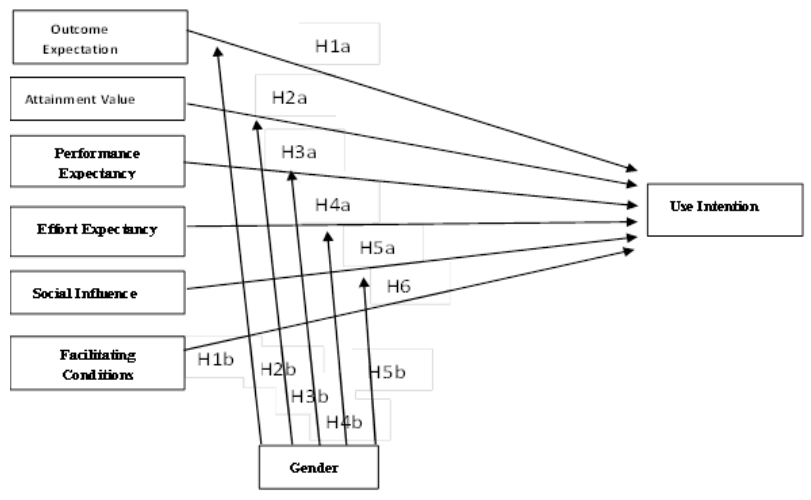

Fig. 1. Reseach framework.

\section{Data Analysis Method}

Structural equation modeling analysis is mainly used to analyze the structure of this study established UTAUT study module. The main analysis method using the Partial Least Square (PLS) as a research model analysis tools with the software Smart PLS 2.0.

\section{DATA ANALYSIS AND DISCUSSION}

The research data analysis is mainly divided into the questionnaire test data analysis and learning effectiveness analysis. Students take exam in the same day in the classroom. Total of 105 questionnaires are received. Deduct an invalid questionnaires, a total of 104 effective samples were used in the descriptive statistical analysis, confirmatory factor analysis (reliability and validity) and structural equation modeling analysis.

\section{A. ANCOVA}

This study carries out the analysis of the effectiveness of learning, control group traditional group, based on the traditional way of teaching face-to-face. The test sample was taken from the first and second semesters have to attend freshman calculus internship training, a total of 256 people. Experimental group 1 is online group that uses Moodle online teaching. The effective sample size is 63 students. The experimental group 2 is a mixed group that also participates in traditional face-to-face courses as well to participate in online Moodle teaching. The effective sample size is 41 students. Each group of raw pretest and posttest scores and the number of each group number are shown in Table I.

TABLE I: TEST RESULTS

\begin{tabular}{|c|c|c|c|}
\hline Group & $\begin{array}{c}\text { Pretest } \\
\text { average } \\
\text { (covariance) }\end{array}$ & $\begin{array}{c}\text { Posttest average } \\
\text { (Dependent } \\
\text { variables) }\end{array}$ & $\mathrm{N}$ \\
\hline Traditional group & 74.74 & 62.80 & 256 \\
\hline Mixed group & 49.26 & 48.80 & 41 \\
\hline Online group & 66.06 & 52.61 & 63 \\
\hline Total & 63.35 & 59.43 & 360 \\
\hline
\end{tabular}

Homogeneity of with-in regression coefficient test is the experimental treatment group, based on the covariates $(\mathrm{X})$ to predict the dependent variable $(\mathrm{Y})$ resulting regression coefficient (slope) to be equal, that each of the regression line to be parallel to each other before ANCOVA compare. Table II shows the SPSS 12.0 for regression coefficients within the group of this study sample homogeneity test table.

TABLE II: HOMOGENEITY OF REGRESSION COEFFICIENT TEST

\begin{tabular}{|c|c|c|c|c|c|}
\hline Source & $\begin{array}{c}\text { Type III Sun } \\
\text { of Squares }\end{array}$ & df & $\begin{array}{l}\text { Mean } \\
\text { Square }\end{array}$ & $\mathrm{F}$ & Sig. \\
\hline $\begin{array}{l}\text { Corrected } \\
\text { Model }\end{array}$ & 71626.336(a) & 5 & 14325.267 & 80.533 & .000 \\
\hline Intercept & 668.069 & 1 & 668.069 & 3.756 & .053 \\
\hline Group & 1225.680 & 2 & 612.840 & 3.445 & .033 \\
\hline $\begin{array}{l}\text { The total score } \\
\text { of the last term }\end{array}$ & 36345.167 & 1 & 36345.167 & 204.323 & .000 \\
\hline $\begin{array}{l}\text { Group* The } \\
\text { total score of } \\
\text { the last term }\end{array}$ & 734.993 & 2 & 367.497 & 2.06 & .128 \\
\hline Error & 62969.927 & 354 & 177.881 & & \\
\hline Total & 1406113.000 & 360 & & & \\
\hline
\end{tabular}

Homogeneity test results of the regression coefficients in Table II group (group * the total score of the last term) $\mathrm{F}$ value is 2.066; Significant p-value $=0.128>0.05$, below the level of significance, to accept the null hypothesis, said three sets of regression line slope are the same. It means the relationship between the covariates (total score of the First Term) and the dependent variable (this semester midterm grades) will not differ from the independent variable entry level of the different. It is comply with the assumed of homogeneity of with-in regression coefficient, that we can continue to do ANCOVA.

\section{1) Analysis of covariance}

Table III is an ANCOVA test summary table. Exclude the impact of pre-test scores (covariates) on the post-test scores (the dependent variable), the effects of the independent variables on the dependent variables test of F-value $=6.141$, significant $\mathrm{p}$-value $=0.002<0.05$, achieve the significant level and experimental treatment effect is significant. It 
means the post-test scores of the subjects will vary because of the different ways of teaching methods.

TABLE III: ANCOVA TEST SUMMARY TABLE

\begin{tabular}{|c|c|c|c|c|c|}
\hline Source & $\begin{array}{l}\text { Type III } \\
\text { Sun of } \\
\text { Squares }\end{array}$ & df & $\begin{array}{c}\text { Mean } \\
\text { Square }\end{array}$ & $\mathrm{F}$ & Sig. \\
\hline $\begin{array}{l}\text { Corrected } \\
\text { Model }\end{array}$ & 70891.343(a) & 3 & 23630.448 & 132.053 & .000 \\
\hline Intercept & 261.485 & 1 & 261.485 & 1.461 & .228 \\
\hline $\begin{array}{l}\text { The total score } \\
\text { of the last term }\end{array}$ & 60417.997 & 1 & 60417.997 & 337.632 & .000 \\
\hline Group & 2197.904 & 2 & 1098.952 & 6.141 & .002 \\
\hline Error & 63704.921 & 356 & 178.946 & & \\
\hline Total & 1406113.000 & 360 & & & \\
\hline Corrected Total & 134596.264 & 359 & & & \\
\hline
\end{tabular}

TABLE IV: MULTIPLE AFTERWARDS PAIRWISE COMPARISON

\begin{tabular}{|c|c|c|c|c|c|c|}
\hline \multirow{2}{*}{ (I) Group } & \multirow{2}{*}{ (J) Group } & \multirow{2}{*}{$\begin{array}{c}\text { Mean } \\
\text { Difference } \\
(\mathrm{I}-\mathrm{J})\end{array}$} & \multirow{2}{*}{$\begin{array}{l}\text { Std. } \\
\text { Error }\end{array}$} & \multirow{2}{*}{ Sig.(a) } & \multicolumn{2}{|c|}{$\begin{array}{l}\text { 95\% Confidence } \\
\text { Interval }\end{array}$} \\
\hline & & & & & $\begin{array}{l}\text { Lower } \\
\text { Bound }\end{array}$ & $\begin{array}{l}\text { Upper } \\
\text { Bound }\end{array}$ \\
\hline \multirow[t]{2}{*}{$\begin{array}{l}\text { Mixed } \\
\text { group }\end{array}$} & $\begin{array}{l}\text { Tradition } \\
\text { group }\end{array}$ & $6.584(*)$ & 2.514 & .009 & 1.640 & 11.527 \\
\hline & $\begin{array}{l}\text { Online } \\
\text { group }\end{array}$ & $9.756(*)$ & 2.784 & .001 & 4.281 & 15.232 \\
\hline \multirow[t]{2}{*}{$\begin{array}{l}\text { Tradition } \\
\text { group }\end{array}$} & $\begin{array}{l}\text { Mixed } \\
\text { group }\end{array}$ & $-6.584(*)$ & 2.514 & .009 & -11.527 & -1.640 \\
\hline & $\begin{array}{l}\text { Online } \\
\text { group }\end{array}$ & 3.173 & 1.920 & .099 & -0.603 & 6.948 \\
\hline \multirow[t]{2}{*}{$\begin{array}{l}\text { Online } \\
\text { group }\end{array}$} & $\begin{array}{l}\text { Mixed } \\
\text { group }\end{array}$ & $-9.756(*)$ & 2.784 & .001 & -15.232 & -4.281 \\
\hline & $\begin{array}{l}\text { Tradition } \\
\text { group }\end{array}$ & -3.173 & 1.920 & .099 & -6.948 & .603 \\
\hline
\end{tabular}

On the Table IV after pairwise comparison table can be obtained multiple comparison of covariates is adjusted averages of the qualitative differences between the groups compared by multiple post hoc comparison table can be found:

- Mixed results are significant in the traditional group and the online group.

- Online Group results with traditional group results are not significantly different.

\section{B. Measurement Model}

\section{1) Reliability analysis and validity analysis}

Into the social and behavioral science research, reliability assessment in general can be divided into four indicators, namely test-retest reliability, alternative-form reliability, split-half reliability and internal consistency reliability. Regardless of test-retest reliability, alternative-form reliability and split-half reliability, all can be called internal consistency reliability. And Cronbach's $\alpha$ internal consistency reliability can adopt the most widely reliability indicators [9], [10]. Nunnally [11] has indicated 0.7 to be an acceptable reliability coefficient.

In the validity Analysis part of this study, confirmatory factor analysis of the Partial Least Squares (PLS) construct measurement model fit test, to test each construct adequate convergent validity and discriminant validity. The following sequence analysis of convergent validity and discriminant validity.

\section{2) Convergent validity analysis}

In this study, based on Anderson and Gerbing [12] suggested convergent validity analysis criteria, Bagozzi and
Yi [13] proposed confirmatory factor analysis evaluation criteria and Gefen, Straub and Boudreau [14] goodness-of-fit indicators recommended data to assess. Assess standard includes: (a) the factor loadings of the indicators respective fields significant; (b) The composite reliability of various dimensions is higher than 0.7; (c) Average Variance Extracted (AVE) is higher than 0.5 but we can accept 0.4 . Because Fornell and Larcker said that if AVE is less than 0.5, but composite reliability is higher than 0.6 , the convergent validity of the construct is still adequate [15]. We used PLS various aspects of data analysis to estimate parameters to calculate the dimensions of composite reliability and average extracted variance.

The reliability analysis and convergent validity analysis is obtained. This study various aspects of internal consistency reliability Cronbach's $\alpha$ values range between 0.719 and 0.924 , all of this are higher than the reliability standard 0.7 . To said consistency reliability of the dimensions within reach significance level that the four dimensions of the framework of this study has some reliability. In convergent validity, in addition to this study the factor loadings of the items to help condition (FC1) data is 0.616 , the rest of the items are to reach the level of significance 0.7 threshold; Each dimensions composite reliability (CR) are between 0.838 and 0.946, higher than the standard 0.7; Each dimensions Average Variance Extracted (AVE) are between 0.565 and 0.815 , higher than the standard 0.5. Comply with the aforementioned scholars convergent validity of each dimension inspection standards, the various aspects of this study have convergent validity.

\section{3) Discriminant validity analysis}

In this study, based on Gaski and Nevin test the discriminant validity of the two criteria: (1). Correlation coefficient between the two dimensions of less than 1 ; (2). The correlation coefficient of the two dimensions less than the individual Cronbach's $\alpha$ reliability coefficient, it means two dimensions have discriminant validity [16]. The other based on the practice of Fornell and Larcker, the test discriminant validity criteria: (3) The correlation coefficient of the two dimensions less than the square root of the AVE, said two dimensions has discriminant validity [15], [16]. This study using the PLS correlation coefficient matrix analysis of each measure variables. In this study the correlation coefficient of the two dimensions are less than 1 , in line with the standards set by the aforementioned scholars; and the correlation coefficient of the two different dimensions are smaller than the dimensions of Cronbach's $\alpha$ reliability coefficient, conform to those of the second criterion. Said the various aspects of this study is in line with Gaski and Nevin proposed test discriminant validity of the two criteria, and discriminant validity [16].

\section{4) Structural model}

When completed reliability and validity testing in PLS measurement model, next is the path for the PLS model coefficient test and predict estimated structural model analysis. In model path coefficient test part to test the relationship between the dimensions of research, analysis of whether the path coefficients significant to the study hypothesis test. PLS method does not default allocation, therefore do not need to test whether the information is in line 
with the assumption of a normal distribution; On the other hand PLS path coefficient significant p-value of the test, so in order to estimate whether the path coefficients significantly, Felsenstein [17] recommend using BootStrap method. That is the use of the t-value to estimate the p-value, to test the significance of coefficient the carried out to determine the hypothesis whether was established [18]. In the present study, the path coefficient test is test method BootStrap using SmartPLS software default; while the predictive power of the model is estimated to determine the use of R-squared.

\section{5) Path coefficient test}

The path coefficients represent the strength and direction of the relationship between the variables. When the path coefficient is positive, indicating a positive influence; when is a negative value as compared to the negative influence. Causal model and observed variables and latent variables do hypothesis testing, after the test, we can get the relevant data, in order to determine whether the path has a significant, and to estimate the assumption results whether established.

\section{6) $R$-squared value of the model predict}

$\mathrm{R}$-squared value is the exogenous variables endogenous variables can explain the variance in the percentage representatives of the predictive power of the research model, its values ranging between 0 and 1 . When the larger the value, the better the explanatory power of the model. In general, $\mathrm{R}$-squared value> 0.67 with practical value, the $\mathrm{R}$-squared value represents a moderate explanatory power between 0.33 and 0.66 , R-squared value between 0.19 and 0.32 is weak explanatory power [19].

After confirm each facet has a certain degree of validity and reliability, the next that further research model established hypothesis test, analysis how the variables of "Outcome Expectation", "Attainment Value", "Performance Expectancy "," Easy-to-use Expectations ", "Social Influence ", and "Help conditions" to work together to affect the " Behavioral intentions". The following data is computed for smart PLS statistical software to collate path coefficient $\mathrm{T}$ values and the corresponding hypothesis and test results of this study sorted out the test results table. The testing results "established" is presented in Table VI.

TABLE VI: The Model Path CoEfFicient AND Hypothesis Validation $(\mathrm{R}-\mathrm{SQU} A R E D=0.7592)$

\begin{tabular}{||c|c|c|c||}
\hline $\begin{array}{c}\text { The relationship between } \\
\text { dimensions }\end{array}$ & $\begin{array}{c}\text { Path } \\
\text { coefficients }\end{array}$ & T-value & Hypothesis \\
\hline \hline $\begin{array}{c}\text { Performance Expectancy } \\
\rightarrow \text { Behavioral intentions }\end{array}$ & 0.336 & 4.468 & H3a \\
\hline $\begin{array}{c}\text { Social Influence } \rightarrow \\
\text { Behavioral intentions }\end{array}$ & 0.186 & 2.817 & H5a \\
\hline $\begin{array}{c}\text { Help conditions } \rightarrow \\
\text { Behavioral intentions }\end{array}$ & 0.160 & 2.005 & H6a \\
\hline $\begin{array}{c}\text { Gender X Performance } \\
\text { Expectancy } \rightarrow \text { Behavioral } \\
\text { intentions }\end{array}$ & -0.235 & 2.939 & H3b \\
\hline \hline $\begin{array}{c}\text { Remark : T values> 1.96 reached * significant ; T values> 2.58 reached } \\
* * \text { significant ; T values> 3.29 reached ***significant }\end{array}$ \\
\hline
\end{tabular}

From the above Table VI that this study architecture road map through structural equation modeling analysis to take Partial Least Square (PLS) analysis can be obtained following Fig. 2 study architecture structure mode path analysis shown to summarize instructions. En route the path of the data path for the value of $\mathrm{T}, \mathrm{T}$ value of 1.96 indicates that the path independent variables to the dependent variable reached a significant level and its route to the solid line indicates; $T$ value less than significant standard that route at dotted line. Fig. 2 can also be seen that the degree of behavioral intentions dimensions explained variance reached $76 \%(\mathrm{R}$ square $=0.7592)$, mean this study has practical interpretation value.

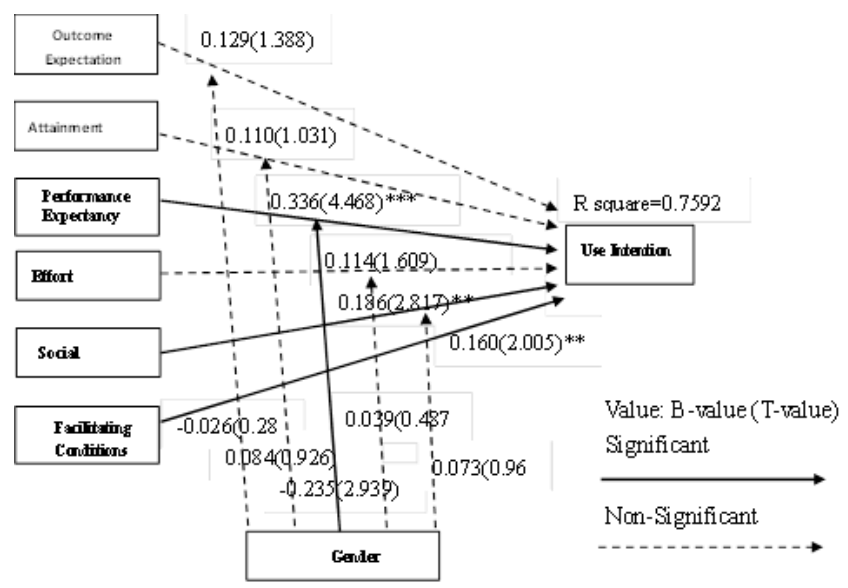

Fig. 2. Research results.

\section{Result and Discussion}

1) In this study, behavioral intentions dimensions $R$ squared value of 0.7592 , the endogenous latent variables R-squared value> 0.67 as having practical value, R-squared $=0.33$ to 0.66 , moderate explanatory power, $\mathrm{R}$-squared $=0.19$ to 0.32 , said explain weak capacity and $76 \%$ of the explained variance of the degree of behavioral intentions dimensions of this study, has a practical value.

2) This study architecture Path "Performance Expectancy $\rightarrow$ Behavioral intentions" the path coefficients $(\mathrm{O})$ is 0.336 , the path coefficient $(\mathrm{M})$ is 0.326 , the $\mathrm{T}$ value after coefficient test is 4.468 . Said research model proven in the significance level $\alpha<0.05$ standard, the performance expectancy has significant positive influence on behavioral intentions, H3a hypothesis of this study is established.

3) This study architecture Path "Social Influence $\rightarrow$ Behavioral intentions" the path coefficients $(\mathrm{O})$ is 0.186 , the path coefficient $(\mathrm{M})$ is 0.183 , the $\mathrm{T}$ value after coefficient test is 2.817. Said research model proven in the significance level $\alpha<0.05$ standard, the social influence has significant positive influence on behavioral intentions, H5a hypothesis of this study is established.

4) This study architecture Path "Help conditions $\rightarrow$ Behavioral intentions" the path coefficients $(\mathrm{O})$ is 0.160 , the path coefficient $(\mathrm{M})$ is 0.150 , the $\mathrm{T}$ value after coefficient test is 2.005. Said research model proven in the significance level $\alpha<0.05$ standard, the help conditions has significant positive influence on behavioral intentions, H6 hypothesis of this study is established.

5) This study architecture Path "Gender X Performance 
Expectancy $\rightarrow$ Behavioral intentions " the path coefficients $(\mathrm{O})$ is -0.235 , the path coefficient $(\mathrm{M})$ is -0.214 , the $\mathrm{T}$ value after coefficient test is 2.939 . Said research model proven in the significance level $\alpha<0.05$ standard, the study regulation variables "gender" for the performance expectancy to behavioral intentions path has significant positive influence, $\mathrm{H} 3 \mathrm{~b}$ hypothesis of this study is established.

6) In this study, H1a, H1b, H2a, H2b , H4a, H4b, and H5b hypothesis of this study are not established based on the path coefficients $\mathrm{O}$, the path coefficient $\mathrm{M}$, the $\mathrm{T}$ value, where the significance level $\alpha$ are all less than 0.05

\section{CONCLUSIONS}

We get the following main conclusions from two aspect, Technology acceptance behavior and learning achievement. Study confirmed in Technology acceptance behavior: (1) The performance expected is positive significant impact on behavioral intentions. (2) Social Influence is positively significant impact on behavioral intentions. (3) Help condition is positive significant impact on behavioral intentions. (4) Adjustment variables gender performance expectations to behavioral intentions path forward significant impact. (5) The degree of influence behavioral intentions dimensions explained variance of $76 \%$, with the practical interpretation.

Study in learning achievement confirmed: (1) Mixed group of students learning achievement than traditional groups and online groups of students learning achievement. (2) Students attending classes online group and traditional group teaching methods, there was no significant difference in learning achievement between the two groups. Learned from the results, performance expected, Social Influence and Help condition is helpful for students to use Moodle system. In terms of learning achievement, the mixed group of students learns achievement better than the online group and traditional group, while no significant difference in the effectiveness of online group and traditional group learning.

\section{REFERENCES}

[1] J. Gil-Flores, J. J. Torres-Gordillo, and V.-H. Perera-Rodríguez, "The role of online reader experience in explaining students' performance in digital reading," Computers \& Education, pp. 653-660, March 2012.

[2] R. C. Clark and E. Mayer, E-learning and the science of instruction: Proven guidelines for consumers and designers of multimedia learning. Pfeiffer, 2011

[3] V. Venkatesh, M. G. Morris, G. B. Davis, and F. D. Davis, "User acceptance of information technology: Toward a unified view," Mis Quarterly, pp. 425-478, 2003.

[4] E. M. Van Raaij and J. J. L. Schepers, "The acceptance and use of a virtual learning environment in China," Computers \& Education, vol. 50, no. 3, pp. 838-852, 2008.

[5] C. Keller, S. Hrastinski, and S. Carlsson, "Students' Acceptance Of E-Learning Environments: A comparative study in Sweden and Lithuani," presented at the Proceedings of the Fifteen European Conference on Information Systems, 2007.

[6] C.-M. Chiu and E. T. G. Wang, "Understanding Web-based learning continuance intention: The role of subjective task value," Information \& Management., vol. 45, no. 3, pp. 194-201, 2008.

[7] M. Dougiamas and P. Taylor, Moodle: Using learning communities to create an open source course management system, 2003.
[8] W. H. Rice, Moodle e-learning course development, Packt publishing.

[9] J. R. A. Santos, "Cronbach's alpha: A tool for assessing the reliability of scales," Journal of extension, no. 2, 1999.

[10] P. E. Shrout and J. L. Fleiss, "Intraclass correlations: uses in assessing rater reliability," Psychological bulletin, vol. 420, no. 2, 1979.

[11] J. Nunnally, Psychometric methods, New York: McGraw, 1978.

[12] J. C. Anderson and D. W. Gerbing, "Structural equation modeling in practice: A review and recommended two-step approach," Psychological bulletin, vol. 411, no. 3, 1988.

[13] R. P. Bagozzi and Y. Yi, "On the evaluation of structural equation models," Journal of the academy of marketing science, no. 1, pp. 74-94, 1988.

[14] D. Gefen, D. W. Straub, and M. C. Boudreau, Structural equation modeling and regression: Guidelines for research practice, 2000.

[15] C. Fornell and D. F. Larcker, "Evaluating structural equation models with unobservable variables and measurement error," Journal of marketing research, pp. 39-50, 1981.

[16] J. F. Gaski and J. R. Nevin, "The differential effects of exercised and unexercised power sources in a marketing channel," Journal of marketing research, pp. 130-142, 1985

[17] J. Felsenstein, "Confidence limits on phylogenies: an approach using the bootstrap," Evolution, vol. 39, no. 4, pp. 783-791, July 1985

[18] L. K. Molinari, R. Abratt, and P. Dion, "Satisfaction, quality and value and effects on repurchase and positive word-of-mouth behavioral intentions in a B2B services context," Journal of Services Marketing, no. 5, pp. 363-373, 2008

[19] W. W. Chin, B. L. Marcolin, and P. R. Newsted, “A partial least squares latent variable modeling approach for measuring interaction effects: Results from a Monte Carlo simulation study and an electronic-mail emotion/adoption study," Information Systems Research, no. 2, pp. 189-217, 2003.

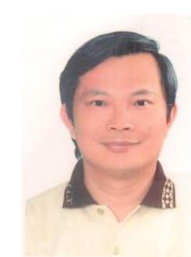

Chun-Che Huang received his Ph.D. degree in Industrial Engineering from the University of Iowa, Iowa City, and his M.S. degree in Operations Research from Columbia University, New York, NY. He is a Professor in the Department of Information Engineering, National Chi Nan University, Taiwan and directs the Laboratory of Intelligent Systems and Knowledge Management (the ISKM Lab.). He is interested in intelligent systems, knowledge management, and data mining. He has published research papers in journals sponsored by various societies.

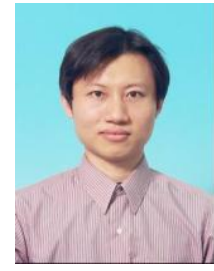

Yu-Min Wang is an associate professor in Information Management at National Chi Nan University in Taiwan. $\mathrm{He}$ received his $\mathrm{Ph} . \mathrm{D}$. degree in Information Management at National Sun Yat-Sen University in Taiwan. His research interests include enterprise information system, information system adoption, electronic commerce, e-learning, and knowledge management.

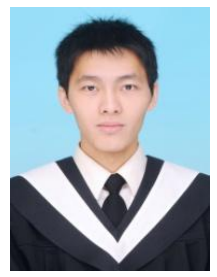

Tsin-Wei Wu is a graduate student in national Chi Nan University. $\mathrm{He}$ is interested in e-learning and data mining.

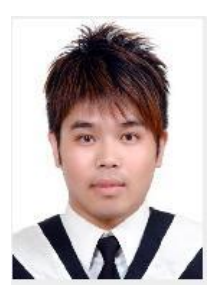

Pei-An Wang is a graduate student in national Chi Nan University. He is interested in rough set theory and e-learning platform. 